\title{
39 \\ BIOLOGICAL TISSUE FOR HEART VALVE SUBSTITUTES
}

\author{
M.M. BLACK, P. LAWFORD, J.L. STOVES and E.A. TROWBRIDGE
}

\begin{abstract}
There are currently two major categories of commercially available heart value substitutes, namely, mechanical or bioprosthetic. In the case of the latter there are again two principal types:

chemically treated and frame mounted natural porcine valves;

frame mounted valves in which the leaflets are made from

chemically treated biological tissue, usually bovine pericardium.
\end{abstract}

This contribution is concerned with the second of the above valve categories and in particular with those prostheses constructed from treated tissue. The techniques and protocols for tissue treatment are described and details are given of the measurements used to assess the efficacy of different treatment regimes. These latter tests include a comprehensive analysis, both theoretical and experimental of the mechanical behaviour of fresh and treated tissue.

This work is reported by the submitted abstract. Further details can be found in Lawford, P.V., Stoves, J.L. and Barker, A.T. (1983). Evaluation of chemically treated tissue for human implantation. Life Support Systems, 1, supp1.1, Proc.Eur.Soc.artif.Organs. 